\title{
Barrier layer in the South China Sea during summer 2000
}

\author{
Lili Zeng ${ }^{1}$, Yan $\mathrm{Du}^{1,2}$, Shang-Ping $\mathrm{Xie}^{2}$, Dongxiao Wang ${ }^{1}$ \\ 1 Key Laboratory of Tropical Marine Environmental Dynamics, South China Sea Institute of \\ Oceanology, Chinese Academy of Sciences, Guangzhou, P. R. China \\ 2 International Pacific Research Center and Department of Meteorology, SOEST, University of \\ Hawaii, Honolulu, Hawaii
}

Corresponding author: Yan DU, Key Laboratory of Tropical Marine Environmental Dynamics, South China Sea Institute of Oceanology, Chinese Academy of Science, 164 West Xingang Road, Guangzhou, China, 510301. Email address: duyan@scsio.ac.cn

Citation: Zeng, L., Y. Du, S.-P. Xie, and D. Wang, 2009: Barrier layer in the South China Sea during summer 2000. Dyn. Atmos. Oceans, 47, 38-54.

\begin{abstract}
Using temperature-salinity profiles obtained from a cruise in summer 2000, the structure and formation of the barrier layer (BL) in the South China Sea (SCS) are investigated. Fresh water flux, ocean circulation, and wind stirring are important for BL formation, depending on regions. In the eastern SCS, Philippine mountains induce heavy rainfall, resulting in a fresh water cap at the surface and the formation of a thick wide spread BL. In the northwestern basin on the lee of the Annam Cordillera range, by contrast, a rain shadow reduces fresh water flux, which along with wind-induced upwelling, prevents the BL forming. Southeast of Vietnam, a thick BL forms as the Mekong River plume is advected by the northeastward western boundary current and its offshore extension. In the southeastern basin, the surface water is mixed deeply under the strong southwesterly monsoon, unfavorable for the BL formation despite heavy rainfall. In the Luzon Strait, the east/southeastward surface Ekman drift carries fresh SCS surface water, riding on the intruding Kuroshio meander that carries well-mixed, warm and saline water. The vertical overlapping of these two water masses gives rise to a thick BL.
\end{abstract}

Keywords: barrier layer; South China Sea; orographic effect; surface fluxes; ocean circulation 


\section{Introduction}

Ocean stratification with a surface isothermal layer (IL) deeper than the mixed layer (ML) is recognized as early as 1936 on Meteor cruises (Defant, 1961). The salinity-stratified IL between the ML and the top of the thermocline is referred as a barrier layer (BL) as it acts as a barrier to turbulent entrainment of cold thermocline water into the ML (Godfrey and Lindstrom, 1989; Lukas and Lindstrom, 1991). In the equatorial Pacific between $10^{\circ} \mathrm{N}$ and $25^{\circ} \mathrm{N}$, surface freshwater fluxes and strong wind bursts are main mechanisms for modulating the BL formation (Ando and McPhaden, 1997). In the subtropical North Pacific, the subduction of high saline water is responsible for the BL formation in winter (Sato et al., 2004). In the tropical Atlantic, Silva et al. (2005) investigate the role of continental river flows in the formation of shallow pycnocline. Recently, many studies begin to investigate the BL in marginal seas. Chu et al. (2002) reveal the existence of the BL in Sulu and Celebes Seas. Shenoi et al. (2004) study the influence of remote forcing on the BL in the southeastern Arabian Sea. In the Bay of Bengal, surface circulation redistributes the low salinity waters and changes the distribution of BL during monsoon seasons (Vinayachandran et al., 2002; Thadathil et al., 2007).

The South China Sea (SCS) is a large tropical marginal sea under strong monsoon influence. The prevailing winds are southwesterly in summer and northeasterly in winter (Liu and Xie, 1999). The SCS connects the western Pacific and the eastern Indian Ocean via many straits. Among these straits, the Luzon Strait is of most importance, where the Kuroshio intrusion is regarded as one of the most important processes to the SCS ocean circulation $(\mathrm{Qu}$, 2000; Qu et al., 2000, 2004, 2005, and 2006; Gan et al., 2006; Wang et al., 2006a; Yu et al., 2008). The SCS basin is surrounded by mountains, many higher than $500 \mathrm{~m}$, such as the Annam Cordillera range in western Vietnam and mountain ranges on the Philippine islands. Xie et al. (2006) reveal that Asian narrow mountain ranges anchor monsoon convection centers. As the southwest summer monsoon impinges on narrow mountains, moisture-laden air is forced to rise, causing intense convection on the windward side. Much of orographic precipitation falls over or flows through rivers into the ocean. Around the SCS, the Pearl River, Red River, and Mekong River are three largest (Fig. 1). Their volume transports show large seasonal variations. Take the Mekong River as an example; the river runoff during July-October accounts for about $70 \%$ of the annual discharge ( $\sim 5.2 \times 10^{11} \mathrm{~m}^{3}$, Dai and Trenberth, 2002$)$, about $16 \%$ of the total rainfall in the SCS basin during the same time $\left(\sim 3.2 \times 10^{12} \mathrm{~m}^{3}\right)$. The SCS receives fresh water from both local rainfall and river discharge.

Several studies investigate the BL in the SCS. Using in situ observations, Wu et al. (2001) and Zhu and Qiu (2002) describe the spatial structure of BL in the southern SCS. Pan et al. (2006a, b) discuss the BL distribution over the northeastern and central SCS. Using a climatology derived from historical observations, Du (2002) and Du et al. (2004) study the 
seasonal cycle of ML and BL, and relate them to monsoonal winds and surface heat fluxes. With the summer monsoon onset in May, increased winds stir the upper ocean and a thick ML forms with uniform temperature and salinity. In the presence of strong rainfall from June to October, fresh water forms a shallow ML. The BL isolates the isohaline surface layer from the cool thermocline.

The paucity of in situ observations has limited the above studies to describing general features of the BL, and its formation mechanism over the SCS remains unclear. The present study investigates the spatial distribution of the BL and its formation mechanism in the summer SCS. We analyze cruise observations in summer 2000, a year that can be regarded as normal (Wang et al., 2006b) without a strong El Niño/Southern Oscillation (ENSO) event. Satellite measurements are used to study dynamical and thermodynamical processes important for the BL formation. We attempt to relate the formation of SCS BL to atmospheric processes such as surface winds and precipitation. The BL affects the heat exchange between the ML and thermocline, and thereby between the ocean and atmosphere, processes important for the maintenance of warm pool in the SCS (Chu and Chang, 1997).

The paper is organized in the following manner. Section 2 describes briefly the data and analysis method. Section 3 presents the background atmospheric and ocean conditions in summer 2000. Section 4 describes the general characteristics of the upper ocean stratification and the BL's horizontal distribution. Section 5 investigates sub-basin features of the BL distribution and its formation mechanism based on cruise transects. Section 6 is a summary and discussion.

\section{Data and methods}

The cruise took place from 2 August to 3 September 2000, a joint survey by the Second and Third Institutes of Oceanography of the State Oceanic Administration, and the South China Sea Institute of Oceanology under the support of the National Key Basic Research Development (so-called 973) Program of China. Temperature and salinity (T-S) are observed from the surface to $2364 \mathrm{~m}$ by conductivity-temperature-depth (CTD) instruments. Most of CTD casts are taken in the deep ocean basin (Fig. 1). Current velocity is recorded along track by an acoustic Doppler current profiler (ADCP) from $19 \mathrm{~m}$ to $455 \mathrm{~m}$ depth, with vertical interval of $4 \mathrm{~m}$. Processed following Qu and Meyers (2005) and Li and Wu (2006), the final dataset includes 189 temperature/salinity profiles, with vertical intervals of about $1 \mathrm{~m}$, and ADCP current velocity.

The depths of ML and IL (MLD and ILD) are calculated from individual profiles and then interpolated onto $0.25 \times 0.25^{\circ}$ grid using the Kriging algorithm (Oliver and Webster, 1990). 
Following Sprintall and Tomczak (1992), we define ILD in terms of a temperature step $\triangle$ $\mathrm{T}=0.8^{\circ} \mathrm{C}$ from near-surface temperature $T_{s}$ at $10 \mathrm{~m}, I L D=z\left(T=T_{s}-\Delta T\right)$. Following Kara et al. (2000), the MLD is defined in terms of density step $\triangle \rho$, equivalent to $\triangle \mathrm{T}$, from the near-surface density $\rho_{\mathrm{s}}, \quad M L D=z\left(\rho=\rho_{\mathrm{s}}+\frac{\partial \rho}{\partial T} \Delta T\right)$. The depth difference between ILDs and MLDs gives the BL thickness (BLT), BLT $=I L D-M L D$. We also construct the BL climatology in August from all available hydrographic T-S profiles in the SCS by combining the World Ocean Database 2001 (WOD01) and historical observations conducted by the South China Sea Institute of Oceanology (Chen, 2005; Liu et al., 2008).

We perform a check of BLT from the 2000 summer cruise against the SCSIO+WOD01 climatology. The following three stations of summer 2000 feature BLT values exceeding three standard deviations: $\left(116.5^{\circ} \mathrm{E}, 8.5^{\circ} \mathrm{N}\right),\left(116^{\circ} \mathrm{E}, 12^{\circ} \mathrm{N}\right)$, and $\left(119^{\circ} \mathrm{E}, 16.5^{\circ} \mathrm{N}\right)$. These singular observations may be due to small-scale processes induced by the isolated shallows and islands in the region. At these three stations, BLT is replaced with the average within the searching radius of $3^{\circ}$ latitude/longitude.

A suit of satellite measurements are used in this study. Surface winds are obtained from the Quick Scatterometer (QuikSCAT; Liu et al., 2000). Surface geostrophic flow is calculated from merged sea surface height (SSH) anomaly from satellite altimetry and mean SSH diagnosed from the SCSIO+WOD01 climatology of temperature and salinity using P-vector inverse method (Chu et al., 1995). The reference level is set at $1500 \mathrm{~m}$ in the deep basin. We use the Objective Analysis Flux (OAFlux; Yu and Weller, 2007) from the Woods Hole Oceanographic Institution (WHOI), precipitation from the Tropical Rainfall Measuring Mission (TRMM) 3B43-V6 product (Huffman et al., 2007), and evaporation derived from the latent heat component of the OAFlux.

\section{Atmospheric and oceanic conditions}

\subsection{Wind, ocean circulation, and surface fluxes}

Upper ocean stratification is closely related with atmospheric conditions and ocean circulations in the SCS (e.g., Du et al., 2004; Qu et al., 2007). During summer, the southwest monsoonal wind dominates (Fig. 2a). The axis of maximum wind is oriented from southwest to northeast in the open ocean, resulting in negative curls in the southeast and positive curls in the northwest. In the Luzon Strait, the wind stress curl pattern is complicated due to orographic effects (Wang et al., 2008), with positive curls in the middle and negative curls on two sides.

Surface wind drives an Ekman drift in the upper surface layer (Fig. 2b), transporting 
surface water east/southeastward and piling it up west/northwest of Palawan and Kalimantan Islands. Ekman drift is quite uniform in the basin, with typical speed of $\sim 15 \mathrm{~cm} / \mathrm{s}$. Surface geostrophic currents are much stronger, with maximum speed of $\sim 50 \mathrm{~cm} / \mathrm{s}$ (Fig. 2c). Southeast of Vietnam, geostrophic currents are westward intensified, indicative of a strong western boundary current. Forced by the negative wind stress curl, the boundary current forms a recirculation gyre in the south (e.g., Wang et al., 2006c). In the literature (Xie et al., 2003; Fang et al., 2002; Cai et al., 2002), the recirculation gyre is called the South Vietnam Anti-cyclonic Eddy or Nansha Anti-cyclonic Eddy. At $\sim 12^{\circ} \mathrm{N}$, the boundary current leaves the coast, turns into an eastward jet called the Vietnam offshore current (Xie et al., 2003; Gan and $\mathrm{Qu}, 2008)$. This offshore current then meanders to the north in the central SCS, forced by the positive wind curl in the northwestern basin. The current eventually separates into two branches to exit the SCS through the Luzon and Taiwan Straits. In the Luzon Strait, the Kuroshio exhibits a meander, flowing into the SCS in the south and flowing out in the north. Ship-board ADCP observations ( $\mathrm{Li}$ and $\mathrm{Wu}, 2006)$ show a similar current pattern.

The net surface heat flux in OAFlux is generally downward over the entire basin (Fig. 3a), ranging from $20 \mathrm{~W} / \mathrm{m}^{-2}$ to $90 \mathrm{~W} / \mathrm{m}^{-2}$. There are two minima $\left(<20 \mathrm{~W} / \mathrm{m}^{2}\right)$, located in the southern $\left(108^{\circ} \mathrm{E}, 8^{\circ} \mathrm{N}\right)$ and eastern central $\left(118^{\circ} \mathrm{E}, 12^{\circ} \mathrm{N}\right)$ basin, respectively. Surface heat flux increases northwestward, exceeding $80 \mathrm{~W} / \mathrm{m}^{2}$ off North Vietnam where winds and sea surface temperature (SST) are low on the lee of the Annam Mountains inhibiting surface evaporation.

Summer precipitation displays large spatial variations under strong orographic effects (Xie et al., 2006; Xu et al., 2008; Fig. 3b). West of the Philippines, rainfall reaches a maximum of $\sim 600 \mathrm{~mm} / \mathrm{month}$. In the northwest basin, by contrast, there is a clear rain shadow lee of the Annam Cordillera range. Over the Indochina Peninsula, Annam Cordillera anchors a heavy rainfall band that covers the entire Mekong River basin (Fig. 3b). At low latitudes, the river basin-integrated precipitation generally agrees with the river discharge (Dai and Trenberth, 2002). Heavy rainfall over the Mekong River basin implies a strong outflow in summer 2000. Compared to rainfall, evaporation distributes evenly, at 110-140 mm/month (Fig. 3c). Large evaporation coincides with strong winds in the open ocean (Zeng et al., in press), with two maxima around $\left(108^{\circ} \mathrm{E}, 8^{\circ} \mathrm{N}\right)$ and $\left(116^{\circ} \mathrm{E}, 20^{\circ} \mathrm{N}\right)$. Generally, evaporation is less important than rainfall for the distribution of fresh water flux in the SCS.

\subsection{Surface salinity and temperature}

Figure 4 shows the vertically salinity and temperature averaged within the ML (Sml and Tml). Southeast of Vietnam, salinity falls below 33 psu. A salinity front of 0.5 psu locates around $\left(108^{\circ} \mathrm{E}, 10^{\circ} \mathrm{N}\right)$ separating the low salinity coastal and saline interior ocean. Southeast of the salinity front, $\mathrm{Tml}$ exceeds $29^{\circ} \mathrm{C}$. To the northwest, the colder water mass indicates strong upwelling, which also is visible in satellite SST and chlorophyll concentration images (not 
shown). Advected by the Vietnam offshore current, part of the upwelling water intrudes into the interior SCS at $13^{\circ}-15^{\circ} \mathrm{N}$ (Xie et al., 2003). In the northern basin, fresh water from the Pearl River expands southward and reaches $20^{\circ} \mathrm{N}$. The spatial pattern of salinity resembles the climatology (Fig. 1); indicating that the salinity in year 2000 is representative for summer in general.

\section{General structure of upper layer stratification}

Atmospheric conditions affect ocean surface stratification. ILD variation is mainly due to the changes in surface wind and heat forcings (Thadathil et al., 2007). The deepening/shoaling of ML results from downward/upward buoyancy flux, involving different processes such as wind stirring, surface cooling/warming, and the horizontal advection in the surface layer (Gordon and Corry, 1991; Lukas and Lindstrom, 1991; Anderson et al., 1996; Kara et al., 2000). Wind stirring is the primary energy source to maintain the turbulent entrainment across the bottom of the ML over the summer SCS, acting against the formation of a thick BL. Positive fresh water and heat fluxes both contribute to a positive buoyancy flux, stabilizing the surface layer. Surface cooling causes oceanic convection, which is important in the middle and high latitudes but has limited effects in tropical oceans. These processes dominate the dynamics of ML and IL, and hence the formation of BL.

\subsection{Summer 2000}

Figure 5 shows ILD and MLD over the SCS. Over a large part of the SCS, ILD is deeper than $40 \mathrm{~m}$ (Fig. 5a), similar to the pattern described by Qu et al. (2007). ILD shoals in the northwestern SCS, forming a shallow band from the southwest of Taiwan to the central Vietnam coast. Deep ILD (>50 m) is found in the following three locations. Southeast of Vietnam, a thick IL belt with maximum close to 60 m spreads northeastward from $\left(109^{\circ} \mathrm{E}\right.$, $\left.10^{\circ} \mathrm{N}\right)$. In the northeast, a deep ILD tongue ( $>40 \mathrm{~m}$ ) extends westward from the Luzon Strait, indicating the influence of the Kuroshio intrusion, which supplies warm western Pacific water into the northern SCS. Near the east boundary, ILD is deeper than $50 \mathrm{~m}$, from the west of Philippines to the northwest of Kalimantan Island, presumably resulted from downward Ekman pumping and coastal downwelling there (Fig. 2a).

The MLD distribution resembles that of ILD in many regions. MLD is generally shallower than ILD by 2-20 m (Fig. 5b), with larger differences in the Luzon Strait and southeast of Vietnam. The shallower MLD and ILD in the northwestern corner is presumably a result of upwelling (Kuo et al., 2000; Ho et al., 2000; Xie et al., 2003).

The ILD-MLD difference indicates the existence of BL (Fig. 5c), which distributes unevenly in the SCS basin. Southeast of Vietnam, BL reaches as thick as $35 \mathrm{~m}$. Figure 6a 
shows the vertical profiles of temperature and salinity at station A near the Mekong River mouth from both the summer 2000 cruise and SCSIO+WOD01 climatology. The climatological profile is reconstructed from the average of all adjacent observations within $1^{\circ}$ latitude/longitude from our selected stations. In summer 2000, ILD and MLD are $65 \mathrm{~m}$ and 18 $\mathrm{m}$, respectively, while BLT is $47 \mathrm{~m}$. A similar BL is also detected in the SCSIO+WOD01 climatology. BL off the South Vietnam coast has never been discussed in the literature presumably because of the lack of CTD observations and heavy smoothing in constructing the climatology (e.g., Du et al., 2004). In the northeast basin, thick BL spreads from the Luzon Strait to the coast of south China. A similar BL structure is also found in summer 1994 (Pan et al., 2006a). At Station B, vertical T-S profiles show that MLD is $14 \mathrm{~m}$, and ILD is $38 \mathrm{~m}$ (Fig. 6b), leading to a $24 \mathrm{~m}$ deep BL. Similar BL is detected in the SCSIO+WOD01 climatology, suggesting that observations in summer 2000 represent the typical BL distribution in the Luzon Strait. In the northwest, no BL exists. In the east/southeast, BL spread over a large region. Monsoonal winds force the warm surface water to pile up against the eastern boundary and the wind curls deepen the thermocline there, which along with enhanced rainfall, give rise to the wide spread BL formation. Vertical profiles at station C (Fig. 6c) off the east boundary show a deep ML and IL with a stable BL from the cruise observation, while a much thinner ML and thicker BL are found in the climatology.

\subsection{Comparison with climatology}

Atmospheric and oceanic conditions in summer 2000 are similar to the climatology. Large rainfall is found on the Cambodian coast, the west slope of the Annams, and west of the Philippines (Fig. 7a). The western boundary current departs the Vietnam coast at $\sim 12^{\circ} \mathrm{N}$, and forms an anti-cyclonic gyre. This current carries fresh water along the western boundary and then flows eastward at $12^{\circ} \mathrm{N}$ into the interior SCS. Southeast of Vietnam, the BL is clearly identified in the SCSIO+WOD01 climatology and shows a tongue-like structure originated from the Mekong River mouth (Fig. 7b). Compared with year 2000 (Fig. 5c), the climatological $\mathrm{BL}$ is generally thinner, presumably because of time averaging. Climatologically, BL also forms in the Luzon Strait because of the Kuroshio intrusion, and expands from the northwest of Kalimantan to the west of Philippines in the southeastern basin, consistent with previous studies (Wu et al., 2001; Du et al., 2004).

Climtologically, BL is found also outside the domain of the summer 2000 cruise. For examples, large rainfall on the Cambodia coast, results in strong surface salinity gradients in favorable of BL formation off the southwest coast of the Indo-China Peninsula (see Figs. 1 and 7b). And in the Northwest SCS, BL forms off the Red River mouth. In the South SCS, orographic rainfall and river discharges facilitate BL (Chen et et al., 2004) formation off Kalimantan, with BLT of $15 \mathrm{~m}$. 


\section{Sub-basin features and formation mechanism}

The BL responses to large-scale atmospheric circulation and air-sea forcing have been discussed in previous studies. Du et al. (2004) find that the Ekman transport and Ekman downwelling facilitate the development of a thick BL in the eastern basin. Several sub-basin features emerge from our analysis, which have never been documented in the literature. For example, a thick BL forms southeast of Vietnam and near the Luzon Strait despite a local rainfall minimum. This section discusses variations and formation mechanisms of BL in these and other regions.

\subsection{BL off Southeast Vietnam}

\subsubsection{Mekong River}

ML water southeast of Vietnam is high in temperature $\left(>29^{\circ} \mathrm{C}\right)$ and low in salinity (Fig. 4). High temperature can be explained by the positive heat flux (Fig. 3a) and the anticyclonic circulation south of the cold filament (Xie et al., 2003). The low salinity cannot be explained by local rainfall, which is at a local minimum. We attribute this salinity minimum to the advection of the Mekong River-diluted water by horizontal circulation. Advected by the west boundary current, the surface fresh water extends northward to $\sim 12^{\circ} \mathrm{N}$ and then eastward into the interior basin.

Along the transect near the Mekong River mouth, there is a thin ( 20 m) fresh surface layer (Fig. 8a). The haline stratification inhibits vertical mixing, resulting in a strong vertical shear and a very thin ML. Positive wind curls slightly lift the thermocline in the northern part of transect. Water warmer than $28^{\circ} \mathrm{C}$ reaches $60 \mathrm{~m}$ deep; with a BL that is about $40 \mathrm{~m}$ thick. Strong along-shore currents support the idea that the freshwater originates from the Mekong River. With a typical horizontal velocity of $40 \mathrm{~cm} / \mathrm{s}$, it takes about 3 days for the fresh water from the Mekong River to reach transect T1. The discharged low-salinity water floats above the warm and saline water. The thin ML, maintained by the Mekong River mouth fresh water outflow, gives rise to a thick BL. This is consistent with the general suggestion of Sprintall and Tomczak (1992) that considerable river runoff plays a dominant role in river mouth regions.

\subsubsection{Along the Vietnam offshore current}

Figure 9 shows temperature, salinity, and ADCP current velocity in transect T2 east of South Vietnam. Strong eastward and northward current dominate the east part of transect (at speed larger than $80 \mathrm{~cm} / \mathrm{s}$ ), indicating the offshore current (coastal jet), separated from the coast at $\sim 12^{\circ} \mathrm{N}$ (Gan and Qu, 2008).

Near the coast, a thick BL is found along the west boundary. The IL is more than $40 \mathrm{~m}$ 
deep, and a halocline forms in the upper 15-40 m. Neither local precipitation minimum nor upwelling explains the surface fresh water, which is likely advected from the Mekong River mouth by the northward western boundary current and then the offshore jet. For a current speed of 40-80 cm/s, it takes 9-18 days for water from the Mekong River mouth to reach the transect. The advection of fresh and warm water from south appears as a complementary factor for maintaining a thin ML. The fresh tongue intrudes into a deep IL, resulting in a thick BL. Further offshore between $113.5^{\circ} \mathrm{E}$ and $115^{\circ} \mathrm{E}$ in the south meander of the Vietnam offshore current, the base of the ML overlaps with the base of the IL, diminishing BL. The influence from the Mekong River runoff and the basin scale circulation are the major causes for BL off southeastern Vietnam.

\subsubsection{Upwelling region}

The salinity increases northward along $15^{\circ} \mathrm{N}$. Transects T3 show the surface water is well mixed. The ML is nearly identical with the IL (Fig. 10). The west side of the transect is in the upwelling region (Fig. 2a). The ocean surface layer is quite sensitive to the upwelling forcing. Positive wind curls force the thermocline to rise toward the west, with a minimum ILD/MLD about $20 \mathrm{~m}$ at the western end of our transect. West of $112^{\circ} \mathrm{E}$, surface flow is weak $(<20 \mathrm{~cm} / \mathrm{s})$. The mechanism for advection of fresh water to maintain the halocline does not hold in the region. East of $115^{\circ} \mathrm{E}$, strong wind mixing maintains a deep ML. Temperature, salinity and density are vertically uniform above the thermocline, with almost no BL.

\subsection{Luzon Strait}

We choose a transect along $121^{\circ} \mathrm{E}$ observed from 27 August to 3 September to investigate the BL along the Luzon Strait (T4). With no ADCP observations available, zonal geostrophic flow is given as an alternative. The zonal current (derived from Fig. 2c) reverses from eastward to westward at $19.25^{\circ} \mathrm{N}$ and turns eastward again north of $21^{\circ} \mathrm{N}$. Between $19.25^{\circ} \mathrm{N}$ and $21^{\circ} \mathrm{N}$, this westward current indicates the Kruoshio intrusion, consistent with previous observations (Centurioni et al., 2004; Tian et al., 2006). The intrusion of the Kuroshio is in the subsurface with its kernel depth around $120 \mathrm{~m}$. The intruded water mass (>34.6 psu) is notably saltier than the SCS water.

Rainfall has a local maximum slightly west of the transect T4 (Fig. 3b). The southwest monsoon forces the fresh surface water southeastward (Fig. 2b). Heavy rainfall associated with typhoon Billis contributes to the fresh surface water. Typhoon Bilis develops into a tropical depression on 18 August and arrives at the Luzon Strait on 22 August. Accumulated rainfall amounts to $200 \mathrm{~mm}$ from 23 to 29 August (Lin et al., 2003). The intensive rainfall in the typhoon forms a fresh surface layer around the Luzon Strait. South of $20^{\circ} \mathrm{N}$, the river discharge from the Luzon Island seems also to contribute to the low salinity of the surface water, favoring the formation of thin BL locally. 
The fresher SCS surface water lies above the Kuroshio water of high salinity (Yu et al., 2008). IL temperature is quite uniform across transect T4. The IL follows the $29^{\circ} \mathrm{C}$ isotherm and varies from $50 \mathrm{~m}$ to $70 \mathrm{~m}$ (Fig. 11a). BLT variations along this transect are mainly due to changes in salinity. As the warm and saline water flows into the SCS, the surface Ekman drift is in the opposite direction carrying the SCS surface water. Because of their different origins, a sharp salinity gradient forms in the upper layer. The deep isothermal water originates from the well-mixed high temperature water in the western Pacific. So the surface fresher water maintains a shallow isohaline layer above thick isothermal water, resulting in a thick BL in the central part of transect T4. North of $20.8^{\circ} \mathrm{N}$, increased temperature and salinity stratification is likely due to strong upward Ekman pumping in July ( $>20 \mathrm{~N} / \mathrm{m}^{3}$, Fig. 11c). This upward movement of the upper thermocline is centered at $\sim 21^{\circ} \mathrm{N}$. Upward Ekman pumping shoals ILD and MLD, thinning BL in the region.

\subsection{Eastern SCS}

Fresh water flux is important but sometimes insufficient for the BL formation. The western Pacific warm pool is an example, where rainfall is associated with westerly wind bursts. The winds and convective mixing can cause the fresh water to mix down and erode the pre-existing or newly formed BL (Cronin and McPhaden, 2002). Transect T5 is selected to investigate this phenomenon in the SCS.

In the eastern SCS, intensive rainfall results in a fresh water cap in summer. Also, the surface Ekman drift transports the low saline water continuously eastward. Salinity is uniform in the upper $60 \mathrm{~m}$ as well as the temperature (Fig. 12a). Why does the fresh water mix so deep here? The surface winds are very strong in July and August, with wind speed amounting to 10 $\mathrm{m} / \mathrm{s}$ in July 2000, much stronger than climatology $(\sim 7 \mathrm{~m} / \mathrm{s})$. These intensive winds enhance the vertical mixing and force a deeper ML. Negative wind stress curl $\left(\sim-10 \times 10^{-8} \mathrm{~N} / \mathrm{m}^{3}\right)$ persists through entire July and August, causing Ekman downwelling near the eastern boundary. In addition, alongshore winds drive coastal downwelling. These two processes play an important role in deepening the ML along the eastern boundary.

Downward vertical motion affects both temperature and salinity stratification. In the presence of strong downwelling-favorable winds, surface fresh water maintained by local orographic rainfall is mixed down close to the thermocline. The BL is not well developed despite heavy rainfall. Similar result is also found in the open ocean, northwest of Kalimantan Island, where rainfall is significant.

\section{Summary and discussion}

The summer 2000 cruise covers almost the entire deep SCS basin. Using CTD profiles, we 
investigate the distribution and formation of the BL. Figure 13 is a schematic diagram summarizing the BL formation mechanisms in the summer SCS. On the basin scale, BL forms in the southern and eastern basins and no BL exists in the northwestern basin. Different processes are identified to contribute to this distribution. They include rainfall induced by orography, the Ekman drift by the southwest monsoon, and upwelling (downwelling) by positive (negative) wind stress curls in the northwest (southeast). Surface heating is positive over the entire basin and not important for the BL spatial distribution.

BL displays interesting sub-basin structures, often due to ocean dynamic processes. Southeast of Vietnam, the advection of fresh water from the Mekong River mouth by the northeastward western boundary currents is important for the maintenance of the shallow halocline. Heavy rainfall in the Mekong River basin may be attributed ultimately to the orographic blockage of the southwest monsoon by the Annam Cordillera range. In the Luzon Strait, the shallow halocline over the well-mixed warm Kuroshio waters is due to the Ekman drift that carries fresh surface water eastward/southeastward. The thick BL in the Luzon Strait results from the intrusion of the saline Pacific water beneath the fresher SCS water, a process similar to that suggested by Lukas and Lindstrom (1991) for the tropical western Pacific. Along the southeastern boundary of the SCS basin, where winds are strong with negative curls, fresh surface water is mixed deeply and BL is thin despite heavy rainfall.

The SCS is part of the Indo-western Pacific Warm Pool, where small changes in SST may induce significant changes in atmospheric deep convection. Persistent BL is important for the maintenance and variability of the western Pacific warm pool. Close relationships are found between the eastern edge of the western Pacific warm pool, high SST, the BL and westerly wind bursts (Maes et al., 2002 and 2006). Recently, Qu et al. (2005, 2006) and Wang et al. (2006a) investigate the role of the South China Sea throughflow in heat and freshwater transport, and suggest that the upper South China Sea may act as a heat capacitor, storing heat in some years and releasing it in others. The BL plays an important role in regulating heat exchange between the thermocline and ML and with the atmosphere. Figure 14 shows the scattering of Tml and Sml versus MLD and BLT. A thicker MLD corresponds to a more saline and slight cooler ML while a thick BLT corresponds to a less saline and slight warmer ML. The latter supports the idea that the BL works as a "barrier" trapping surface heating in the ML. The slope of the BLT regression with Sml is larger than that with Tml, suggesting the important contribution from salinity and fresh water flux/transport. Further studies with atmosphere and ocean models are necessary to understand the full implications of BL for climate in the SCS and adjacent regions.

In the SCS, local oceanic rainfall and runoff from main rivers also show large interannual variations. Besides fresh water flux, the southwesterly winds relax during the summer 
following El Nino (Xie et al., 2003; Wang et al., 2006a), a condition favorable for BL formation. Thus, the BL formation may experience significant interannual variations. Besides, intraseasonal variance during summer reaches a local maximum over the SCS in precipitation (Straub and Kiladis, 2003), wind speed and SST. Intraseasonal fluctuations in southwesterly winds modulate the upwelling off the Vietnam coast (Isoguchi and Kawamura, 2006) and the offshore jet (Xie et al., 2007). These changes in ocean circulation, along with precipitation variability, are likely to cause intraseasonal variations in BL. Further clarifications of the BL formation process require quantitative analyses of upper salinity and temperature fields and air-sea fluxes.

Acknowledgements: Satellite wind products are obtained from Remote Sensing Systems (www.ssmi.com) and the Physical Oceanography Distributed Active Archive Center (http://podaac-www.jpl.nasa.gov/); OAFlux from WHOI (http://oaflux.whoi.edu/). We thank Dr. Ju Chen and Mr. ChangJian Liu for providing the WOD01+SCSIO dataset. This study is supported by Knowledge Innovation Project of the Chinese Academy of Sciences, Natural Science Foundation of China (Grants No. 40640420557, 40576013 and 40876007), and Outstanding Overseas Chinese Scholars Funds of the Chinese Academy of Sciences. S.-P. Xie is supported by the U.S. National Science Foundation, National Aeronautic and Space Administration, and the Japan Agency for Marine-Earth Science and Technology. IPRC/SOEST publication \#xxx/yyy. 


\section{References}

Anderson, S. P., Weller, R. A., Lucks, R. B., 1996. Surface buoyancy forcing and the ML of the western Pacific warm pool observations and 1D model results. J. Climate. 9, 3056-3085.

Ando, K., McPhaden, M. J., 1997. Variability of surface layer hydrography in the tropical Pacific Ocean. J. Geophys. Res. 102, 23063-23078.

Cai, S., Gan, Z., Su, J., Liu, Q., 2002. Three-dimensional baroclinic numerical simulation of the South China Sea circulation's seasonal characteristics. II. Middle and deep circulation. China J. Oceanogr. Limnol. 20, 9-15.

Centurioni, L.R., Niiler, P.P., Lee, D.K., 2004. Observations of inflow of Philippine Sea surface water into the South China Sea through the Luzon Strait. J. Phys. Oceanogr. 34, 113-121.

Chen, J., 2005. Variability of the watermass and circulation in the South China Sea. Ph.D. Dissertation. South China Sea Institute of Oceanology, Guangzhou, 190 pp.

Chen, J., Shi, P., Du, Y., 2004. Intercomparison of rainfall products in South China Sea and its adjacent areas. J. Trop. Oceanogr. 6, 40-51.

Chu, P.C., 1995. P-vector method for determining absolute velocity from hydrographic data. Mar. Technol. Soc. J. 29, 3-14.

Chu, P.C., Chang, C.P., 1997. South China Sea warm pool in boreal spring. Adv. Atmos. Sci. 14, 195-206.

Chu, P., Liu, Q., Jia, Y., Fan, C., 2002. Evidence of a barrier in the Sulu and Celebes Seas. J. Phys. Oceanogr. 32, 3299-3309.

Cronin, M.F., McPhaden, M.J., 2002. Barrier layer formation during westerly wind bursts. J. Geophys. Res. 107, doi: 10.1029/2001JC001171.

Dai, A., Trenberth, K.E., 2002. Estimates of freshwater discharge from continents: latitudinal and seasonal variations. J. Hydrometeorol. 3, 660-687.

Defant, A., 1961. Physical Oceanography, vol. 1. Pergamon Press, New York, 729 p.

Du, Y., 2002. Seasonal dynamics of the mixed layer and thermocline in the South China Sea. Ph.D. Dissertation. Ocean University of China, Qingdao, 240 pp.

Du, Y.,Wang, D., Shi, P., Guo, P., Chen, J., 2004. Seasonal variation of the barrier layer in the South China Sea and its relationship to the sea surface flux. China J. Atmos. Sci. 28, 101-111. Fang,W., Fang, G., Shi, P., Huang, Q., Xie, Q., 2002. Seasonal structures of upper layer circulation in the southern South China Sea from in situ observations. J. Geophys. Res. 107, 3202, doi: 10.1029/2002JC001343. 
Gan, J., Qu, T., 2008. Coastal jet separation and associated flow variability in the Southwest South China Sea. Deep Sea Research I 55, 1-19.

Gan, J., Li, H., Curchitser, E.N., Haidvogel, D.B., 2006.Modeling South China Sea circulation: response to seasonal forcing regimes. J. Geophys. Res. 111, C06034, doi: 10.1029/2005JC003298.

Godfrey, J.S., Lindstrom, E., 1989. The heat budget of the equatorial western Pacific surface ML. J. Geophys. Res. 94, 8007-8017.

Gordon, C., Corry, R.A., 1991. A model simulation of the seasonal cycle in the tropical Pacific Ocean using climatological and modeled surface forcing. J. Geophys. Res. 96, 847-864.

Ho, C.R., Zheng, Q.N., Soong, Y.S., Kuo, N.J., Hu, J.H., 2000. Seasonal variability of sea surface height in the South China Sea observed with TOPEX/Poseidon altimeter data. J. Geophys. Res. 105, 13, 981 - 13, 990.

Huffman, G.J., Adler, R.F., Bolvin, D.T., Gu, G., Nelkin, E.J., Bowman, K.P., Hong, Y., Stocker, E.F., Wolff, D.B., 2007. The TRMM multi-satellite precipitation analysis: quasi-global, multi-year, combined-sensor precipitation estimates at fine scale. J.

Hydrometeorol. 8 (1), 38-55.

Isoguchi, O., Kawamura, H., 2006. MJO-related summer cooling and phytoplankton blooms in the South China Sea. Geophys. Res. Lett. 33, L16615, doi: 10.1029/2006GL027046.

Kara, A.B., Rochford, P.A., Hurlburt, H.E., 2000. An optimal definition for ocean mixed layer depth. J. Geophys. Res. 105, 16, 803-16, 821.

Kuo, N.J., Zheng, Q.N., Ho, C.R., 2000. Satellite observation of upwelling along the western coast of the South China Sea. Remote Sens. Environ. 74, 463-470.

Li, L., Wu, R., 2006. Comment on circulation in the South China Sea during summer 2000 as obtained from observations and a generalized topography-following ocean model. J. Geophys. Res. 111, C03007, doi: 10.1029/2004JC002751.

Lin, I.-I., Liu, W.T., Wu, C.-C., Chiang, J.C., Sui, C.-H., 2003. Satellite observations of modulation of surface winds by typhooninduced upper ocean cooling. Geophys. Res. Lett. 30 (3), 1131, doi: 10.1029/2002GL015674.

Liu, W.T., Xie, X., 1999. Space-based observations of the seasonal changes of South Asian monsoons and oceanic response. Geophys. Res. Lett. 26, 1473-1476.

Liu,W.T., Xie, X., Polito, P.S., Xie, S.-P., Hashizume, H., 2000. Atmospheric manifestation of tropical instability waves observed by QuikSCAT and tropical rain measuring mission.

Geophys. Res. Lett. 27, 2545-2548. 
Liu, C., Du, Y., Zhang, Q.,Wang, D., 2008. Seasonal variation of subsurface and intermediatewater masses in the South China Sea. Oceanol. Limnol. Sin. 39 (1), 55-64.

Lukas, R., Lindstrom, E., 1991. The mixed layer of the western equatorial Pacific Ocean. J. Geophys. Res. 96, 3343-3357.

Maes, C., Picaut, J., Belamari, S., 2002. Salinity barrier layer and onset of El Ni no in a Pacific coupled model. Geophys. Res. Lett. 29 (24), 2206, doi: 10.1029/2002GL016029.

Maes, C., Ando, K., Delcroix, T., Kessler, W.S., McPhaden, M.J., Roemmich, D., 2006.

Observed correlation of surface salinity, temperature and barrier layer at the eastern edge of the western Pacific warm pool. Geophys. Res. Lett. 33, L06601, doi:

10.1029/2005GL024772.

Oliver, M.A., Webster, R., 1990. Kriging: a method of interpolation for geographical information system. Int. J. Geogr. Inform. Syst. 4, 313-332.

Pan, A., Wan, X., Xu, J., Guo, X., Li, L., 2006a. Barrier layer in the northeastern South China Sea and its formation mechanism. China Sci. Bull. 51, 472-479.

Pan, A.,Wan, X., Xu, J., Li, L., 2006b. Barrier layer in the central South China Sea and its formation mechanism. Acta Oceanol. Sin. 28, 35-43.

Qu, T., 2000. Upper layer circulation in the South China Sea. J. Phys. Oceanogr. 30, 1450-1460.

Qu, T., Meyers, G., 2005. Seasonal variation of barrier layer in the southeastern tropical Indian Ocean. J. Geophys. Res. 110, doi: C11003, 10.1029/2004JC002816.

Qu, T., Mitsudera, H., Yamagata, T., 2000. Intrusion of the North Pacific waters into the South China Sea. J. Geophys. Res. 105, 6415-6424.

Qu, T., Kim, Y.Y., Yaremchuk,M., Tozuka, T., Ishida, A., Yamagata, T., 2004. Can Luzon Strait transport play a role in conveying the impact of ENSO to the South China Sea? J. Climate 17, 3643 - 3656.

Qu, T., Du, Y., Meyers, G., Ishida, A.,Wang, D., 2005. Connecting the tropical Pacific with Indian Ocean through South China Sea. Geophys. Res. Lett. 32, L24609, doi: 10.1029/2005GL024698.

Qu, T., Du, Y., Sasaki, H., 2006. South China Sea throughflow: a heat and freshwater conveyor. Geophys. Res. Lett. 33, L23617, doi: 10.1029/2006GL028350.

Qu, T., Du, Y., Gan, J., Wang, D., 2007. Mean seasonal cycle of isothermal depth in the South China Sea. J. Geophys. Res. 112, C02020, doi: 10.1029/2006JC003583. 
Sato, K., Suga, T., Hanawa, K., 2004. Barrier layer in the North Pacific subtropical gyre. Geophys. Res. Lett. 31, L05301, doi: 10.1029/2003GL018590.

Shenoi, S.S.C., Shankar, D., Shetye, S.R., 2004. Remote forcing annihilates barrier layer in southeastern Arabian Sea. Geophys. Res. Lett. 31, 1-4.

Silva, A., Araujo, M., Medeiros, C., Silva, M., Bourles, B., 2005. Seasonal changes in the mixed and barrier layer in the western equatorial Atlantic. Braz. J. Oceanogr. 53, 83-98.

Sprintall, J., Tomczak, M., 1992. Evidences of the barrier layer in the surface layer of the tropics. J. Geophys. Res. 97, 7305-7316.

Straub, K.H., Kiladis, G.N., 2003. Interactions between the boreal summer intraseasonal oscillation and higher-frequency tropical wave activity. Mon.Weather Rev. 131, 945 - 960.

Thadathil, P.,Muraleedharan, P.M., Rao, R.R., Somayajulu, Y.K., Reddy, G.V., Revichandran, C., 2007. Observed seasonal variability of barrier layer in the Bay of Bengal. J. Geophys. Res. 112, C02009, doi: 10.1029/2006JC003651.

Tian, J., Yang, Q., Liang, X., Xie, L., Hu, D., Wang, F., Qu, T., 2006. Observation of Luzon Strait transport. Geophys. Res. Lett. 33, L19607, doi: 10.1029/2006GL026272.

Vinayachandran, P.N., Murty, V.S.N., Ramesh Babu, V., 2002. Observations of barrier layer formation in the Bay of Bengal during summer monsoon. J. Geophys. Res. 107, 8018, doi: 10.1029/2001JC000831.

Wang, D., Liu, Q., Huang, R., Du, Y., Qu, T., 2006a. Interannual variability of the South China Sea throughflow inferred from wind data and an ocean data assimilation product. Geophys. Res. Lett. 33, L14605, doi: 10.1029/2006GL026316.

Wang, C.,Wang,W.,Wang, D.,Wang, Q., 2006b. Interannual variability of the South China Sea associated with El Nino. J. Geophys. Res. 111, C03023, doi: 10.1029/2005JC003333.

Wang, G., Chen, D., Su, J., 2006c. Generation and life cycle of the dipole in the South China Sea summer circulation. J. Geophys. Res. 111, C06002, doi: 10.1029/2005JC003314.

Wang, G., Chen, D., Su, J., 2008. Winter eddy genesis in the eastern South China Sea due to orographic wind jets. J. Phys. Oceanogr. 38, 726-732.

Wu,W., Tomczak, M., Fang, X.,Wu, D., 2001. The barrier layer in the southern region of the South China Sea. China Sci. Bull. 46, 1388-1392.

Xie, S.-P., Xie, Q.,Wang, D., Liu,W.T., 2003. Summer upwelling in the South China Sea and its role in regional climate variations. J. Geophys. Res. 108, 3261, doi: $2003 J C 001867$. 
Xie, S.-P., Xu, H., Saji, N.H., Wang, Y., Liu, W.T., 2006. Role of narrow mountains in large-scale organization of Asian monsoon convection. J. Climate 19, 3420-3429.

Xie, S.-P., Chang, C.-S., Xie, Q.,Wang, D., 2007. Intraseasonal variability in the summer South China Sea: the wind jet, cold filament, and recirculations. J. Geophys. Res. Oceans 112, C10008, doi: 10.1029/2007JC004238.

Xu, H., Xie, S.-P.,Wang, Y., Zhuang,W.,Wang, D., 2008. Orographic effects on South China Sea summer climate. Meteor. Atmos. Phys. doi:10.1007/s00703-008-0309-4.

Yu, L.S.,Weller, R.A., 2007. Objectively analyzed air - sea heat fluxes for the global ice-free ocean (1981 - 2005). Bull. Am.Meteorol. Soc. 88, 527-539.

Yu, Z., McCreary, J.P., Yaremchuk, M., Furue, R., 2008. Subsurface salinity balance in the South China Sea. J. Phys. Oceanogr. 38 (2), 527-539.

Zeng, L., Shi, P., Liu, W. T., Wang, D., in press. Intercomparison of various latent heat flux products in the South China Sea. Adv. Geosci. (OS).

Zhu, L., Qiu, Z., 2002. Seasonal distribution and variation of barrier layer and its influence upon the vertical heat diffusion in the southern South China Sea. Acta Oceanol. Sin. 24, 171 178. 


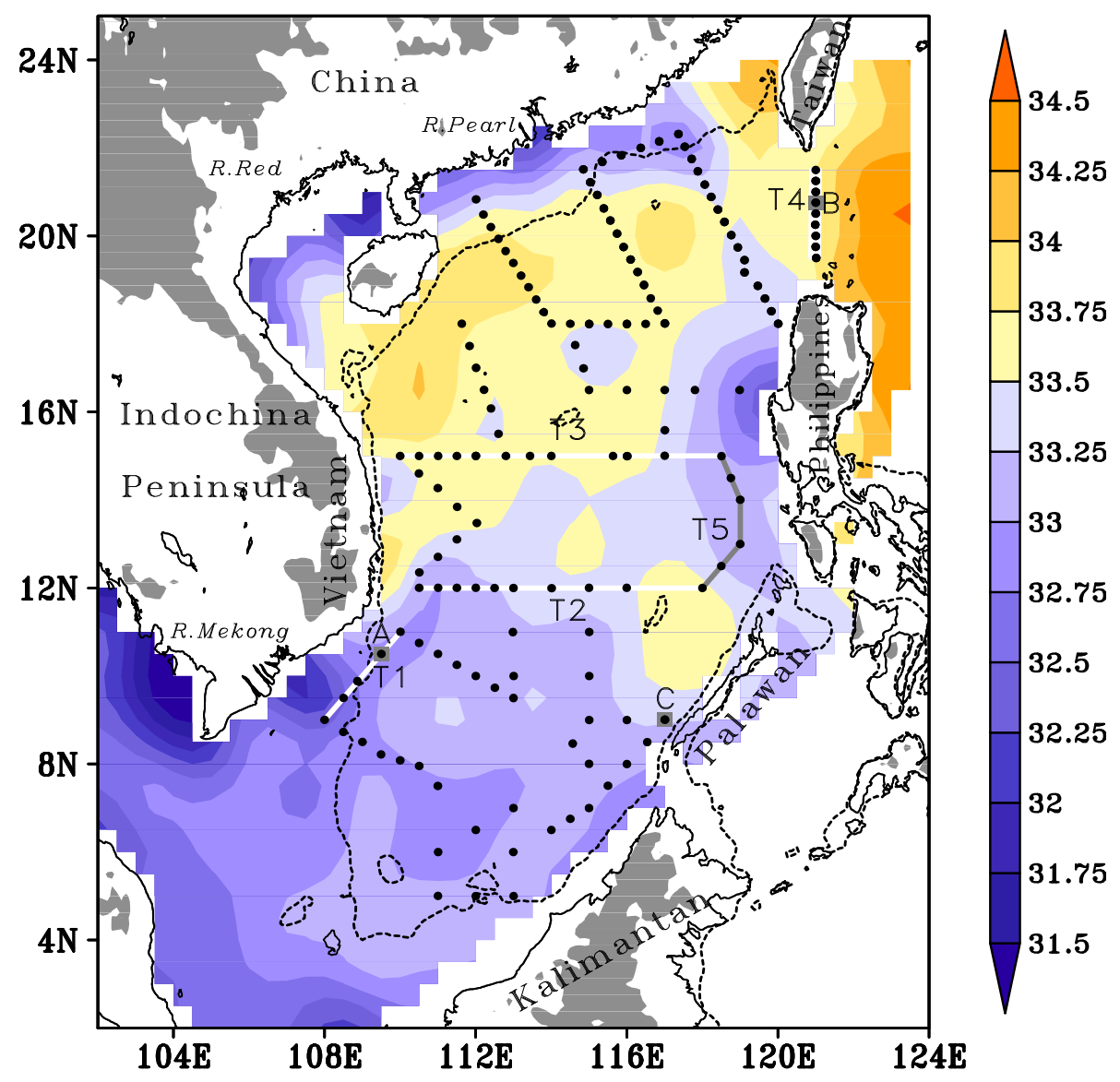

Figure 1 Topography surrounding the South China Sea (SCS). Cruise stations (black dots) in summer 2000, including three selected stations (A, B and C in gray closed squares) and five transects (T1-5 in white/gray lines) for in-depth analysis, are illustrated. Mountains higher than $500 \mathrm{~m}$ are shaded gray while the Pearl River (R. Pearl), Red River (R. Red) and Mekong River (R. Mekong) are marked over land. The 100-m isobath contour (dotted) and the climatology August of sea surface salinity (color shading) from SCSIO+WOD01 are given. 


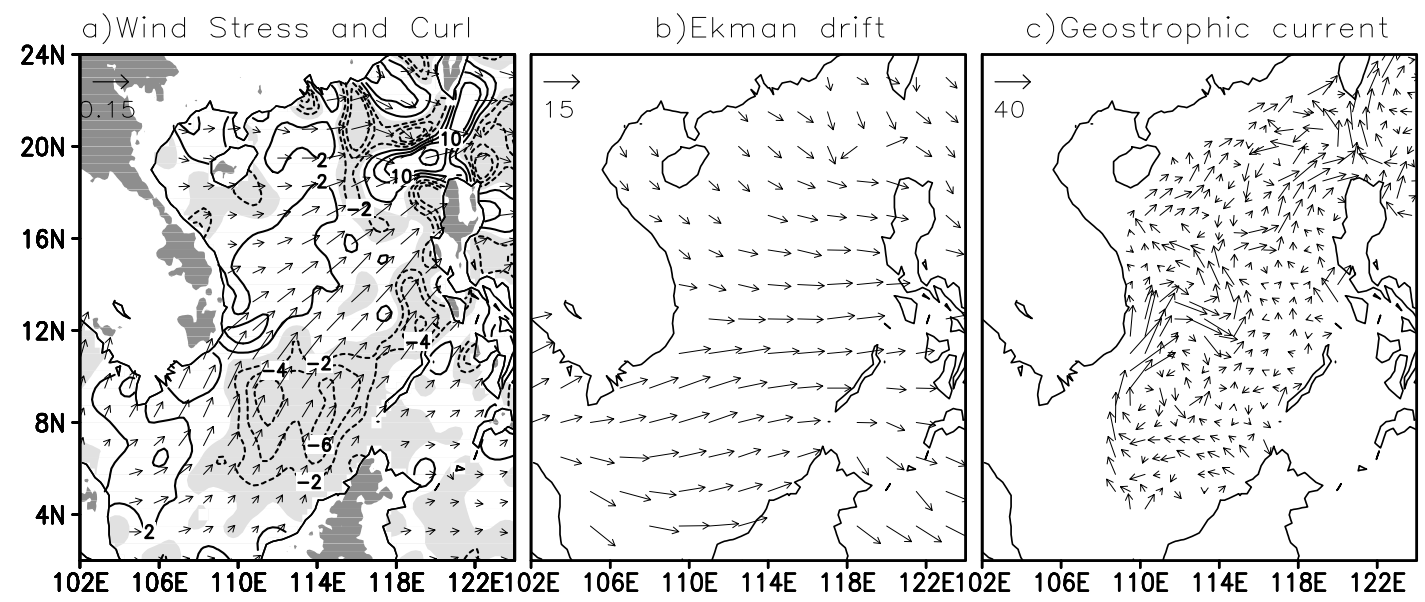

Figure 2 Wind and surface current during July-August 2000. (a) Wind stress (vector; $\mathrm{N} / \mathrm{m}^{2}$ ) and its curl (gray shading and contours; $10^{-8} \mathrm{~N} / \mathrm{m}^{3}$ ) from QuikSCAT; (b) Ekman current velocity $(\mathrm{cm} / \mathrm{s})$ calculated from QuikSCAT winds; and (c) geostrophic current velocity $(\mathrm{m} / \mathrm{s})$ calculated by merging sea surface height (SSH) anomaly from satellite altimetry and mean SSH diagnosed from the SCSIO+WOD01 climatology, currents with water depth shallow than $100 \mathrm{~m}$ are removed.

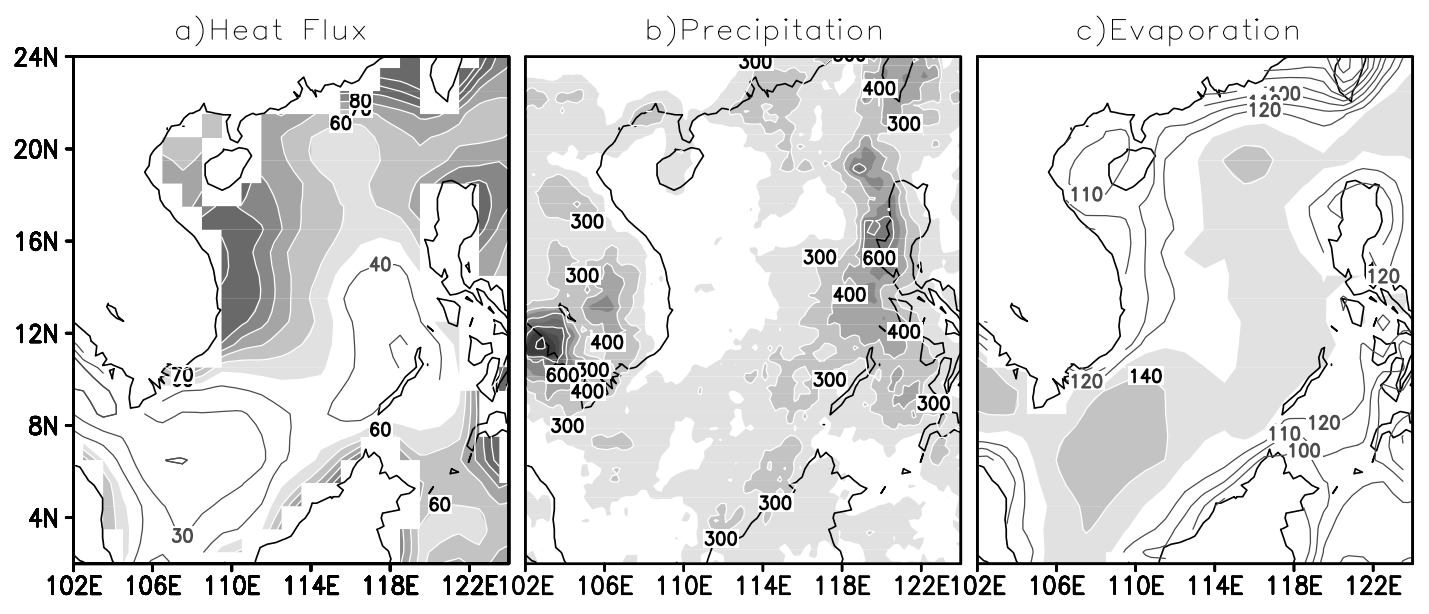

Figure 3 Surface heat and fresh water flux in June-August 2000: (a) net heat flux from the OAFlux (CI: $10 \mathrm{~W} / \mathrm{m}^{2}$ ), (b) TRMM 3B43-V6 precipitation (CI: $50 \mathrm{~mm} / \mathrm{month}$ ), and (c) evaporation from latent heat flux of OAFlux (CI: $50 \mathrm{~mm} / \mathrm{month}$ ). 


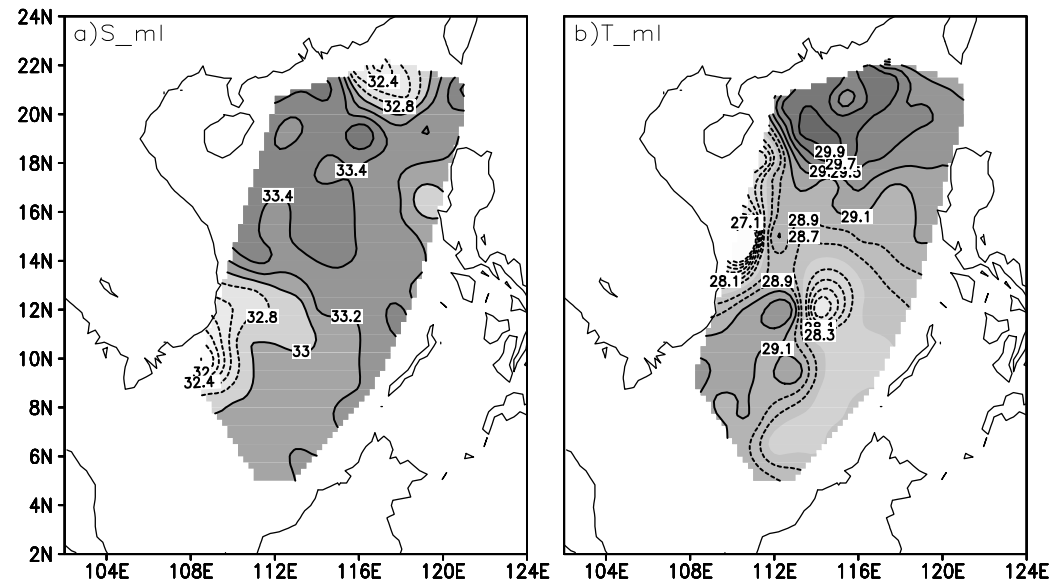

Figure 4 (a) Salinity (Sml; CI: 0.1 psu; dashed contours < 32.2 psu) and (b) temperature (Tml; CI: $0.2^{\circ} \mathrm{C}$; dashed contours $<28.7^{\circ} \mathrm{C}$ ) from the cruise averaged in the mixed layer.

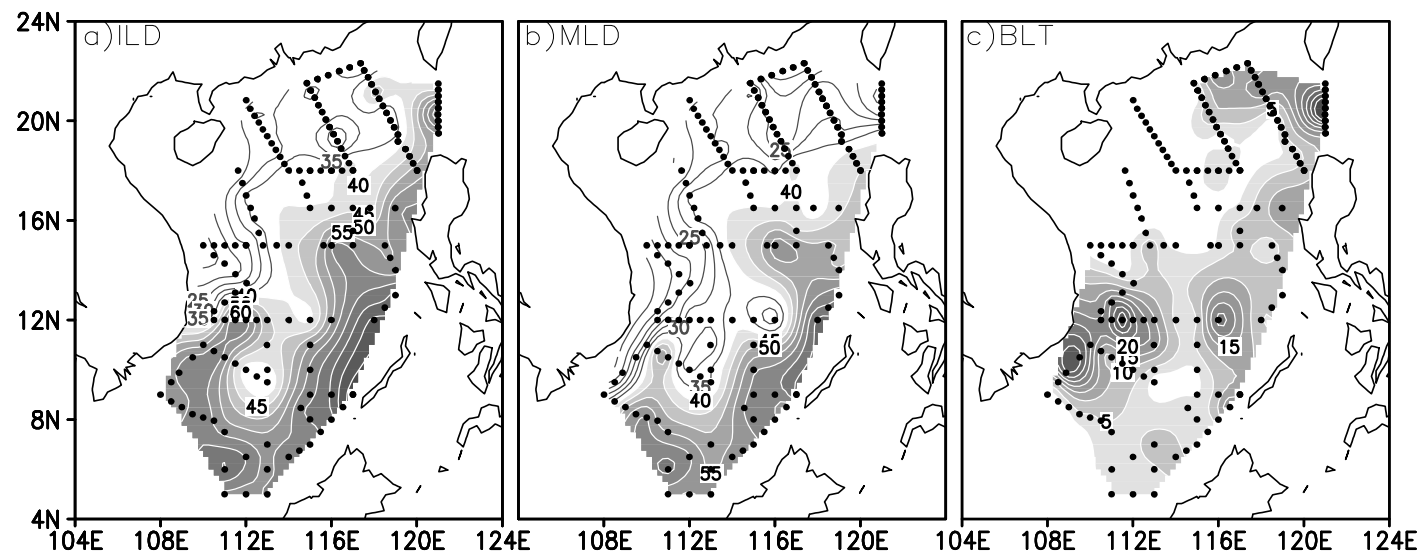

Figure 5 (a) Isothermal layer depth, (b) mixed layer depth, and (c) barrier layer thickness during the summer 2000 cruise. Contour interval (CI) is $5 \mathrm{~m}$. Black dots are observation stations. 

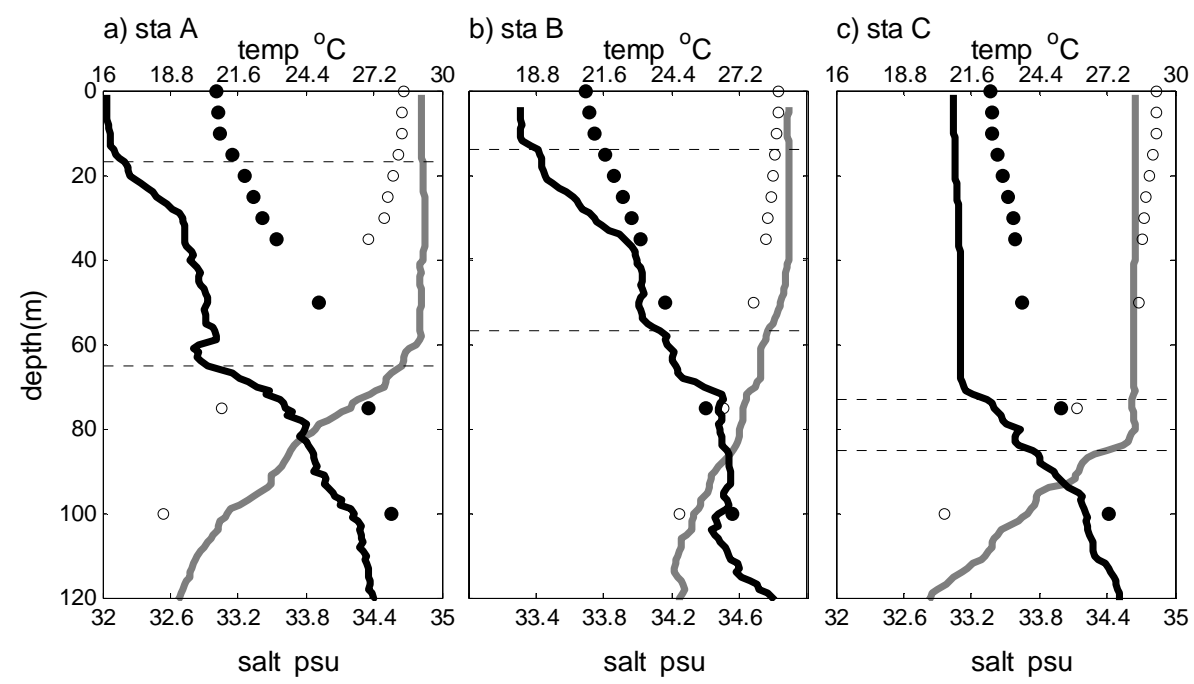

Figure 6 Vertical profiles of temperature (gray) and salinity (black) at stations A, B, and C. Dashed horizontal lines are the mixed layer depth and isothermal layer depth based on cruise data. Climatological temperature (open circle) and salinity (dot) at the same locations from SCSIO+WOD01 are superimposed. Climatological profile is defined as the average of all adjacent observations within $1^{\circ}$ from selected stations.

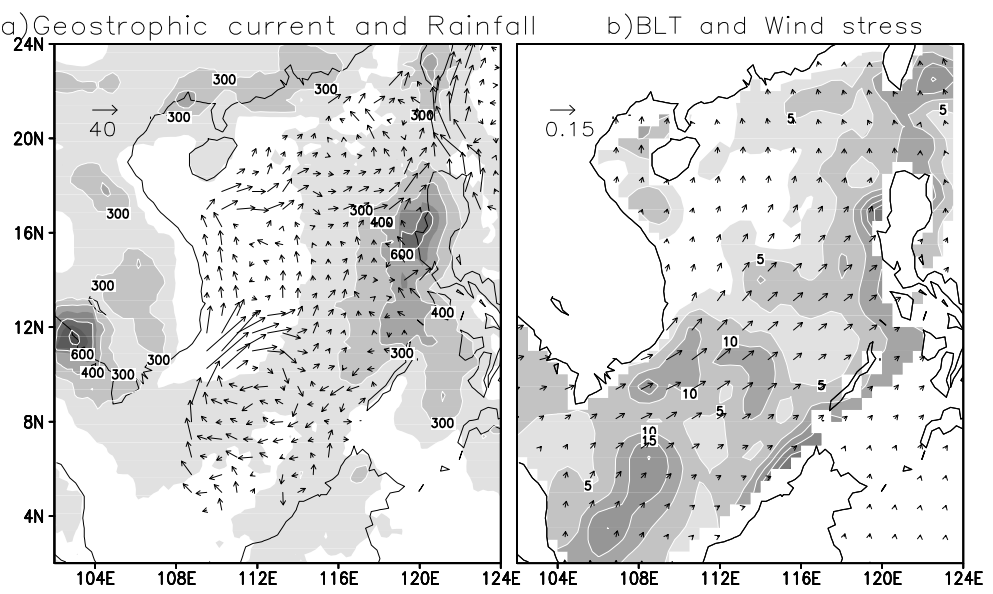

Figure 7 Climatological conditions over and surrounding the SCS. (a) Geostrophic current velocity $(\mathrm{cm} / \mathrm{s})$ by merging altimeter data (1992-2003) and the SCSIO+WOD01 climatology, currents with water depth shallow than $100 \mathrm{~m}$ are removed; and TRMM 3B43-V6 rainfall (1998-2006) for June-August (mm/month). (b) BLT from the August SCSIO+WOD01 climatology and wind stress (vector, $\mathrm{N} / \mathrm{m}^{2}$ ) from QuikSCAT. 


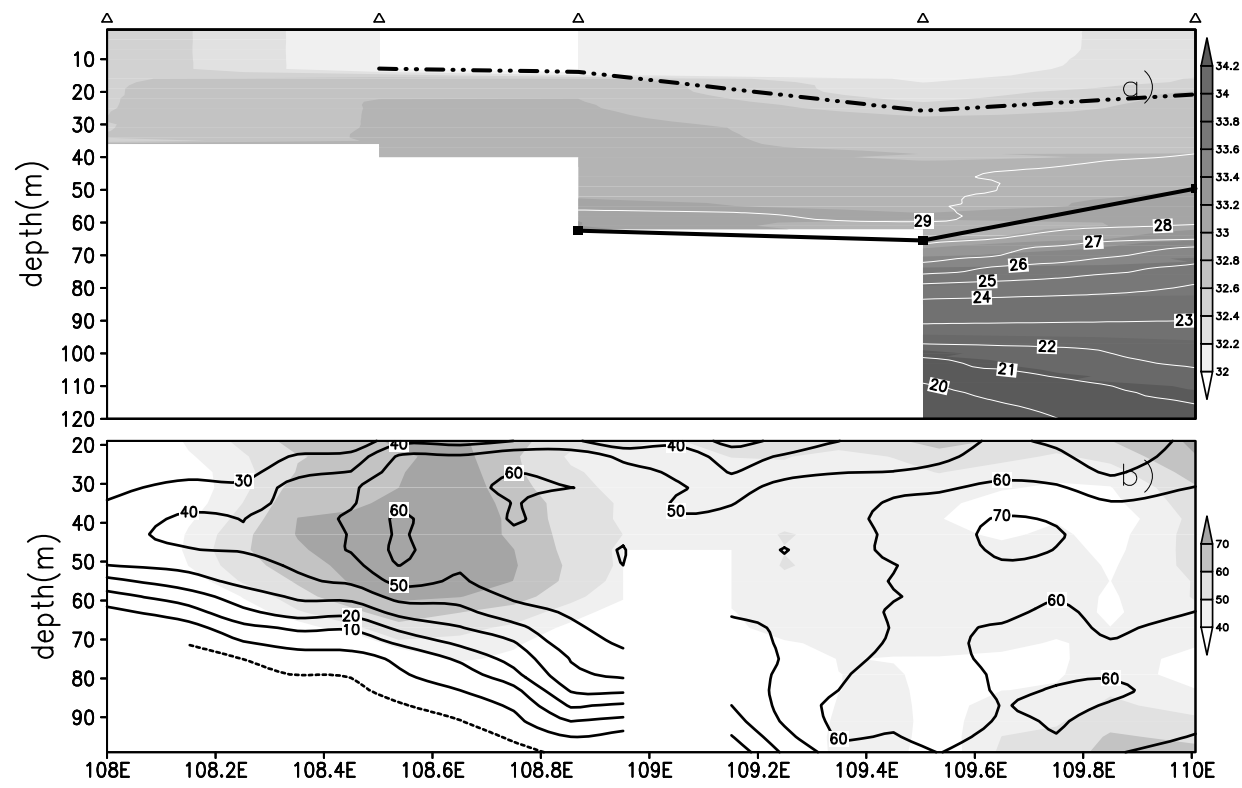

Figure 8 Transect T1 off the Mekong River mouth: (a) salinity (gray shading, CI: 0.1 psu) and temperature (contour, $\mathrm{CI}: 1^{\circ} \mathrm{C}$ ). CTD stations are marked by triangles. Mixed layer depth (thick dashed line) and isothermal layer depth (thick solid line) are superimposed. (b) Zonal (shaded in $\mathrm{cm} / \mathrm{s}$ ) and meridional (contour) velocities from ship-boarded ADCP, with positive denoting eastward or northward. 


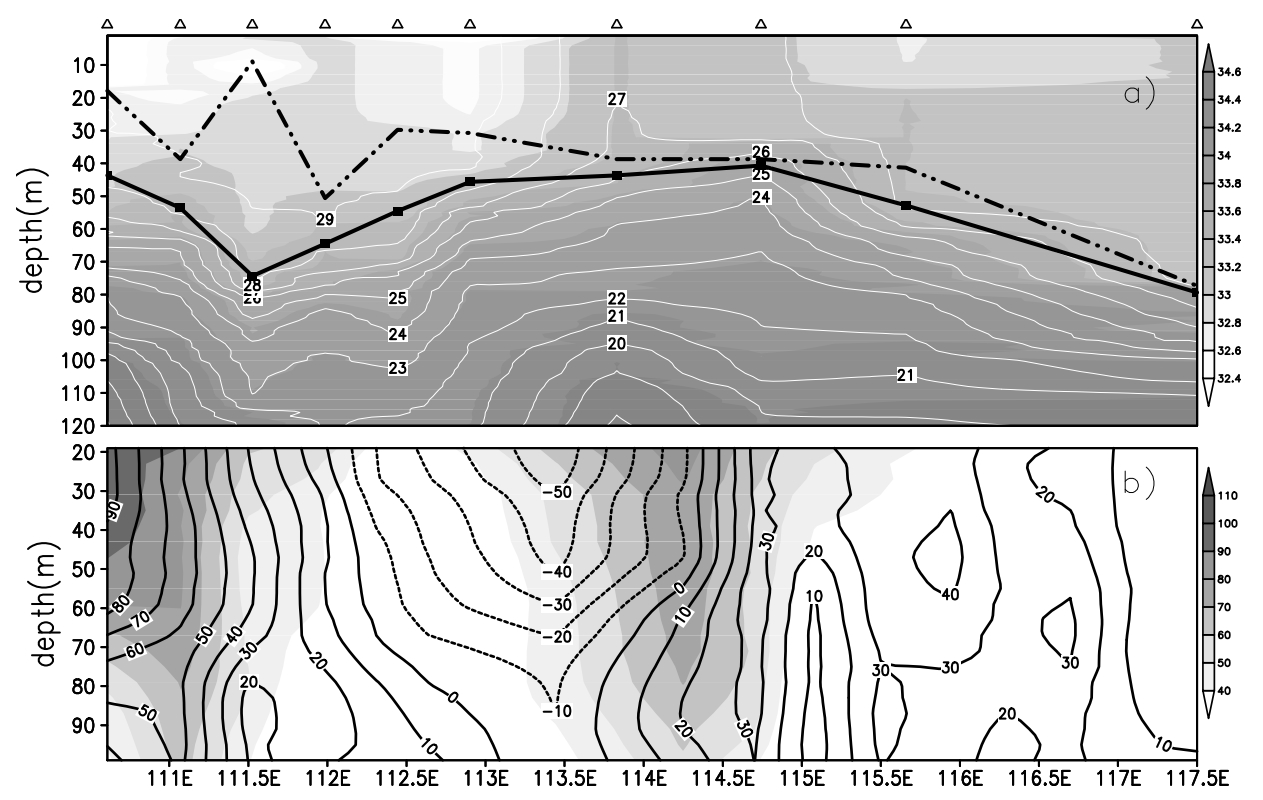

Figure 9 Same as Figure 8 except for Transect T2 along $12^{\circ} \mathrm{N}$.

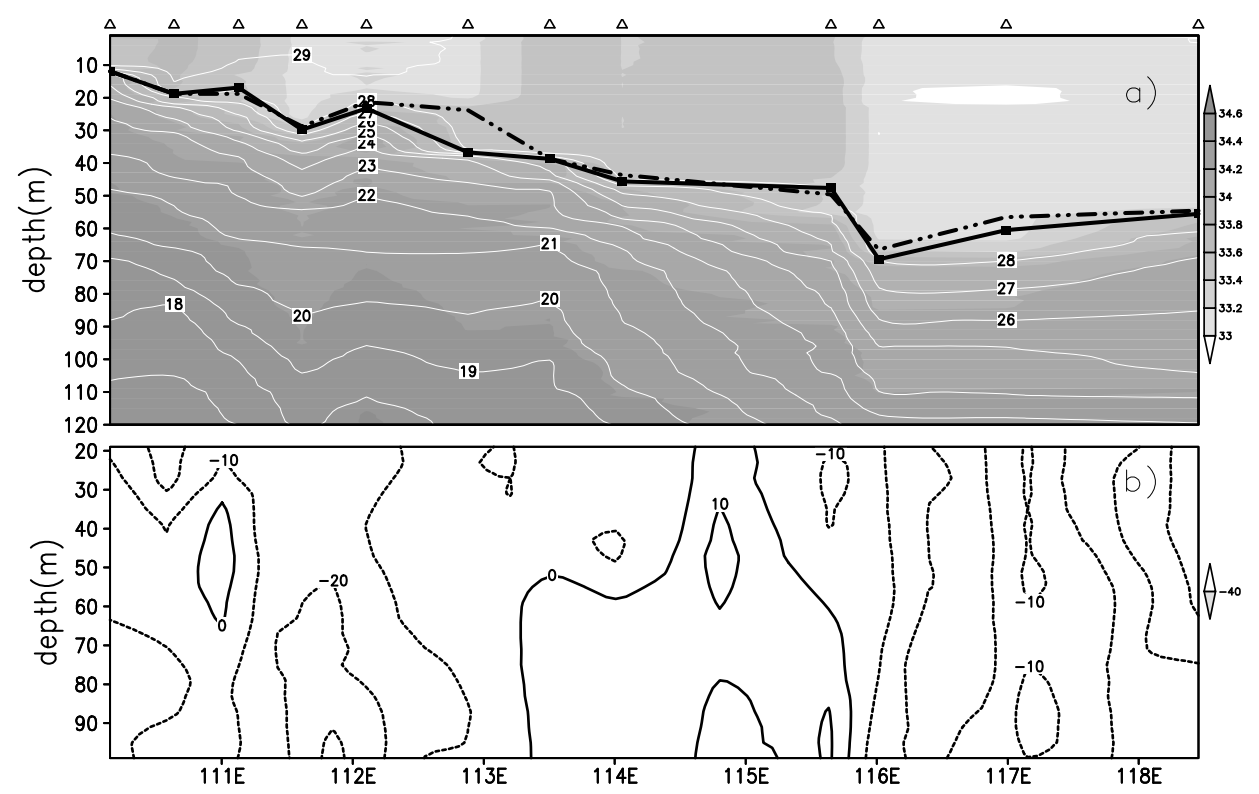

Figure 10 Same as Figure 8 except for Transect T3 along $15^{\circ} \mathrm{N}$. 


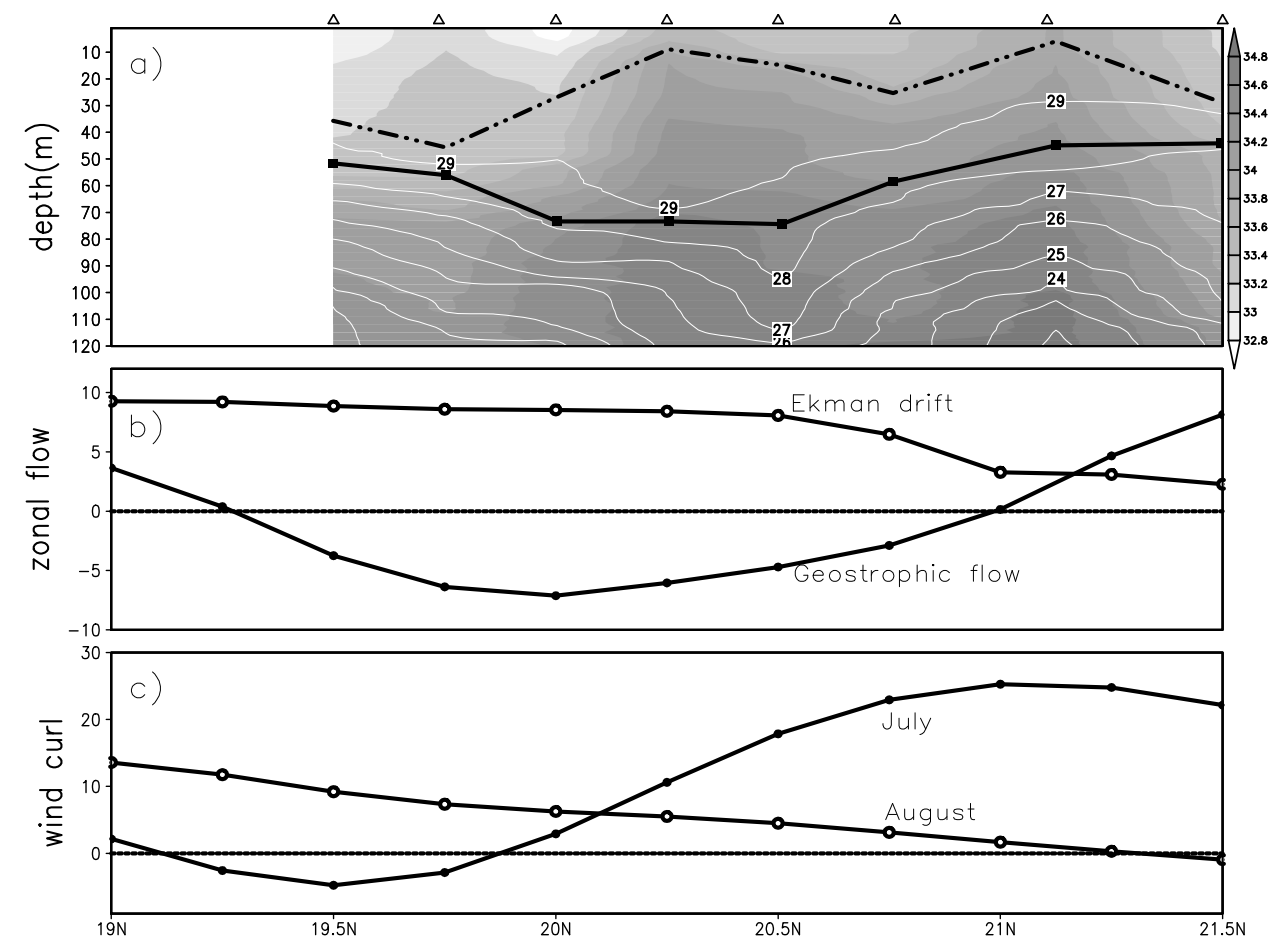

Figure 11 Transect $\mathrm{T} 4$ along $121^{\circ} \mathrm{E}$ in the Luzon Strait, with (a) the same as Figure 7a. (b) Zonal Ekman and geostrophic flow (cm/s), and (c) wind stress curl $\left(10^{-8} \mathrm{~N} / \mathrm{m}^{3}\right)$ in July and August.
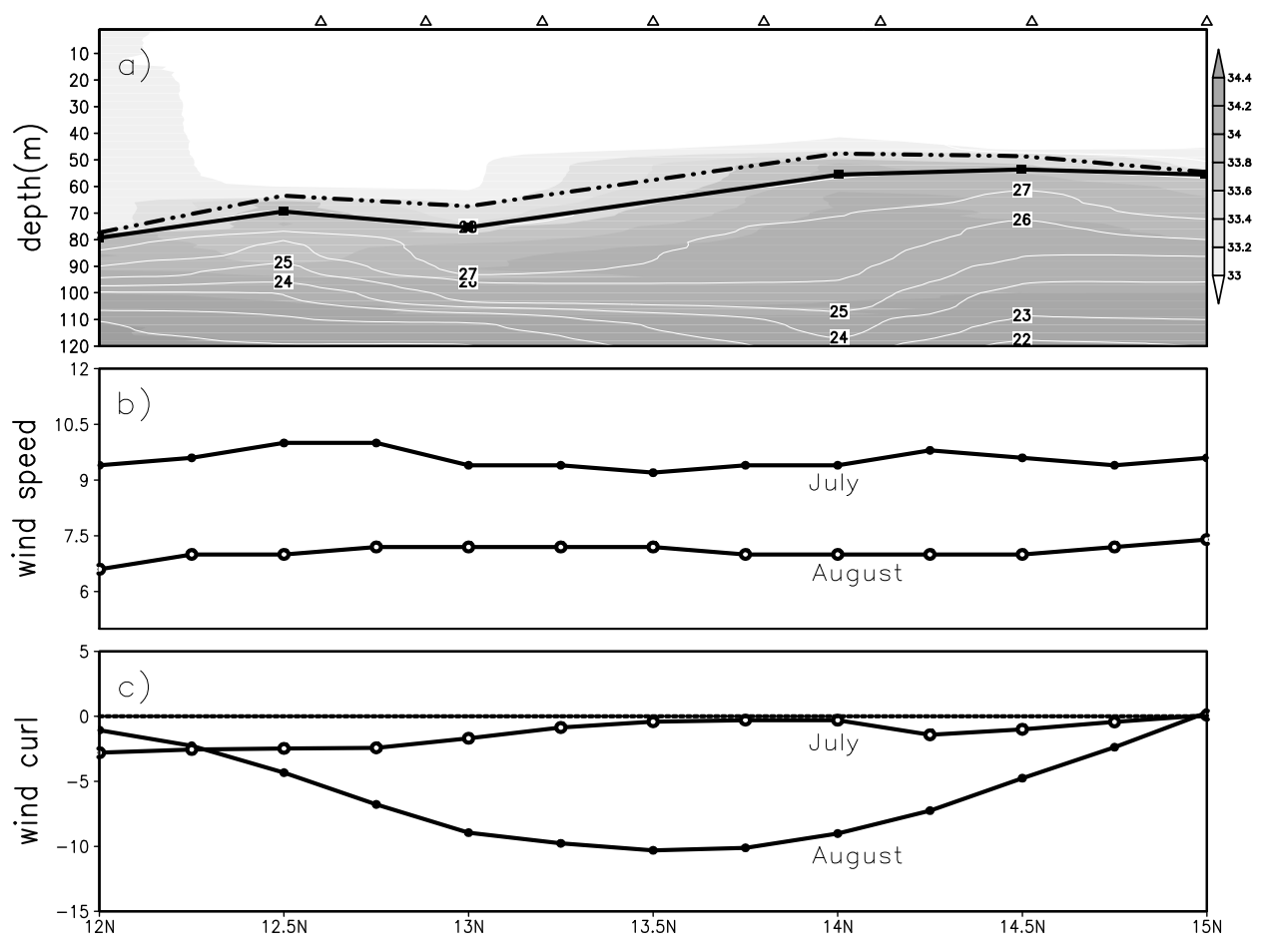

Figure 12 Transect T5 off the southwestern Philippines, with (a) the same as Figure 7a. (b) Wind speed $(\mathrm{m} / \mathrm{s})$ and (c) wind stress curl $\left(10^{-8} \mathrm{~N} / \mathrm{m}^{3}\right)$ in July and August. 


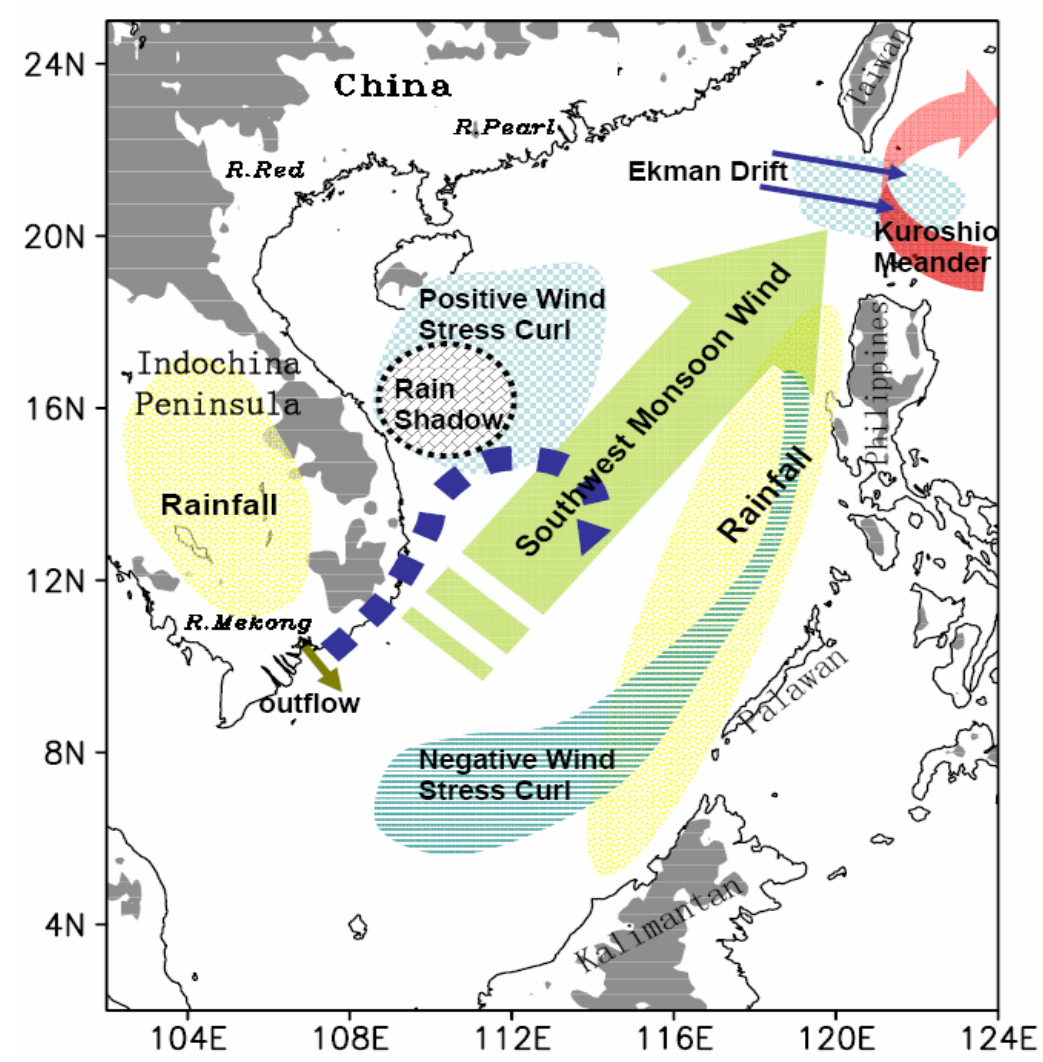

Figure 13 Schematic diagram of the atmospheric and oceanic processes important for the BL formation.
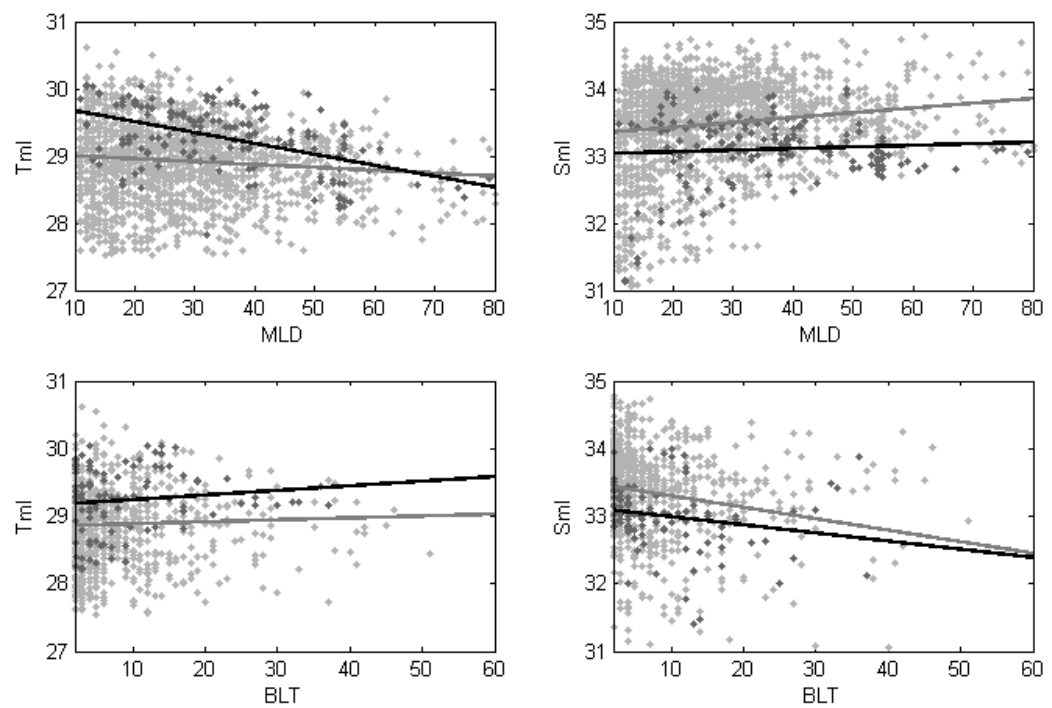

Figure 14 Scatter-diagram of mixed layer temperature $\left(\mathrm{Tml},{ }^{\circ} \mathrm{C}\right)$ and salinity (Sml, psu) vs mixed layer depth (m) and barrier layer thickness (m). Light gray dots are stations from SCSIO+WOD01, thick black dots are form cruise in summer 2000. Light gray (thick black) lines are linear least squares fits for observations form SCSIO+WOD01 (summer 2000). 